\title{
TSH-induced differentiated functions correlate with enhancement of phosphotyrosine phosphatase activity in thyroid cells. Effect of phorbol 12-myristate 13-acetate
}

\author{
E Petitfrère, E Huet, H Sartelet, L Martiny, O Legue and B Haye \\ Université de Reims Champagne Ardenne-IFR 53 Biomolécules, Laboratoire de Biochimie, FRE CNRS 2260, UFR Sciences, Moulin de la Housse, BP 1039, \\ 51687 Reims Cedex 2, France \\ (Requests for offprints should be addressed to E Petitfrère; Email: emmanuelle.petitfrere@univ-reims.fr)
}

\begin{abstract}
TSH-treated pig thyroid cells reorganize into follicle-like structures and exhibit differentiated functions. TSH also induces a phosphotyrosine phosphatase (PTPase) activity evaluated by phosphorylated substrate hydrolysis. Incubation of thyrocytes with various concentrations of 8-bromo-cyclic AMP or forskolin induces an increase of PTPase activity in a dose-dependent manner. During the culture period, adenylyl cyclase sensitivity, protein binding iodine and PTPase activity progressively increase from the first to the fourth day of the culture. Chronic treatment with phorbol 12-myristate 13-acetate (PMA) significantly inhibits PTPase activity during the first $24 \mathrm{~h}$ following
\end{abstract}

PMA addition. GF 109203X, a specific inhibitor of protein kinase $\mathrm{C}$, abolishes the inhibitory effect of PMA. Electrophoresis of membrane extracts allowed us to demonstrate a phosphatase activity at $111 \mathrm{kDa}(\mathrm{p} 111)$. Vanadate inhibits this activity, indicating that p111 is a PTPase. This p111 is significantly reduced in PMAtreated cells. These data suggest that PTPase activity evidenced at $111 \mathrm{kDa}$ is correlated with a differentiated state of primary cultured pig thyroid cells induced by TSH.

Journal of Endocrinology (2001) 169, 603-611

\section{Introduction}

The role of protein phosphorylation in the control of cell growth, proliferation and differentiation has been well described. The majority of these phosphorylations occurs on serine and threonine residues. However, since the discovery of tyrosine kinases, it has become clear that tyrosine phosphorylation also plays an important role in the regulation of cellular functions (Charbonneau \& Tonks 1992, Zhang 1997). The level of tyrosine phosphorylation reflects the balance between protein-tyrosine kinases and phosphotyrosine phosphatase (PTPases). PTPases are hydrolytic enzymes that remove the phosphate group from the phosphorylated tyrosine residue. PTPases constitute a diverse family of enzymes classified into two groups, receptor-like and intracellular PTPases (Streuli 1996). Most studies have focused on intracellular kinases and phosphatases demonstrating the control by protein phosphorylation of many diverse biological events such as differentiation, gene expression, development, cell division and adhesion (Zhang 1997). In porcine thyroid cells, it has been demonstrated that intracellular tyrosine phosphorylation influences follicular organization by regulating focal adhesion assembly (Yap et al. 1997). In rat thyroid cells, a novel receptor-type tyrosine phosphatase gene has been isolated and identified as a differentiation marker (Zhang 1997). Moreover, a transmembrane PTPase called PTP $\mu$ was found to be associated with E-cadherin and involved in the balance between phosphatases and kinases located in adherent junctions (Nilsson et al. 1998). Recently, we have characterized a PTPase in porcine thyroid cells using different phosphorylated substrates and specific inhibitors (Petitfrère et al. 1996). The catalytic domain of this PTPase was located at the outer surface of thyroid cells and its activity was controlled by thyrotrophin (TSH). TSH induces isolated thyroid cells to reorganize into follicle-like structures that exhibit all the thyroidspecific genes (thyroglobulin, thyroperoxidase) and functions (iodide organification, thyroid hormone synthesis and secretion, sensitivity of adenylylcyclase (for a review see Dumont et al. 1992)). TSH regulates the differentiated functions whereas phorbol 12-myristate 13-acetate (PMA), a potent tumour promoter (Boutwell 1974), stimulates thyroid cell proliferation (Takasu et al. 1987). PMA has also been described to induce perturbation of thyroid cell morphology and metabolism such as inhibition of both iodination rate of thyroglobulin and adenylyl cyclase sensitivity and modulation of expression of thrombospondin and collagen (Bachrach et al. 1985, Haye et al. 1985a, Bellon et al. 1994). So, PMA constitutes a 
particularly useful tool for the understanding of the mechanisms leading to follicle disorganization and cell malignant phenotype. The aim of this study was to study the effect of PMA on PTPase activity correlated with a differentiated state of primary cultured pig thyroid cells.

\section{Materials and Methods}

\section{Materials}

Bovine TSH (10 UI/11 mg), okadaic acid and forskolin were from Calbiochem (Chelles, Merck SA, France), malachite green from George T Gure (London, UK), Eagle's minimum essential medium (MEM) from Merieux (Lyon, France), acrylamide from Eurobio (Les Ulis, France), and prestained molecular weight markers from Bio-Rad (Ivry Sur Seine, France). All others products were purchased from Sigma (St Louis, MO, USA).

\section{Cell culture}

Pig thyroid cells were isolated by a discontinuous trypsinization technique and cultured in Eagle's MEM containing $10 \%$ calf serum (control cells) or supplemented with various concentrations of either TSH or forskolin (Fayet 1970, Mauchamp et al. 1979). They were cultured in suspension in Petri dishes (untreated for tissue culture) at $37^{\circ} \mathrm{C}$ in an atmosphere of $5 \% \mathrm{CO}_{2}-95 \%$ air. Cell viability was checked at the end of the experiments and evaluated by Trypan blue exclusion (cell viability: $97 \pm 2 \%$ ).

\section{Phosphotyrosine phosphatase assay}

Thyroid cells were tested for phosphatase activity each day of culture or after a 4-day culture period. Cells $\left(2 \times 10^{6}\right)$ were washed and incubated for $40 \mathrm{~min}$ at $37{ }^{\circ} \mathrm{C}$ in $0.3 \mathrm{ml}$ reaction medium (Tris- $\mathrm{HCl} 100 \mathrm{mM}, \mathrm{pH}$ 7) containing $10 \mathrm{mM}$ phosphotyrosine (P-Tyr). After centrifugation (150 $\mathrm{g}, 5 \mathrm{~min})$, dephosphorylation of P-Tyr was evaluated by measuring the concentration of orthophosphate $(\mathrm{Pi})$ using a colorimetric assay with malachite green as previously described (Petitfrère et al. 1996).

\section{Thyroid protein iodination: $P B\left[^{125} I\right]$}

Washed cells $\left(1 \times 10^{6}\right)$ were incubated at $37^{\circ} \mathrm{C}$ in $350 \mu \mathrm{l}$ Earle's HEPES buffer (pH 7.2) containing $1 \mu \mathrm{Ci} \mathrm{Na}\left[{ }^{125} \mathrm{I}\right]$. After $45 \mathrm{~min}, 650 \mu \mathrm{l}$ Earle's HEPES buffer containing KI $\left(10^{-4} \mathrm{M}\right)$ and bovine serum albumin fraction $\mathrm{V}(5 \mathrm{mg} /$ $\mathrm{ml}$ ) were added, followed by $2 \mathrm{ml}$ cold $20 \%$ (w/v) trichloroacetic acid and the mixture was centrifuged $(500 \mathrm{~g}, 5 \mathrm{~min})$. The resulting pellet was resuspended, washed twice with cold 10\% trichloroacetic acid, and counted as $\mathrm{PB}\left[{ }^{125} \mathrm{I}\right]$ (protein binding iodine) (Haye et al. 1985c).

\section{cAMP assay}

Washed thyroid cells were incubated at $37^{\circ} \mathrm{C}$ in a final volume of $350 \mu$ l Earle's HEPES buffer ( $\mathrm{pH} 7 \cdot 2)$ with isobutylmethylxanthine $\left(10^{-3} \mathrm{M}\right)$ and TSH $(10 \mathrm{mU} / \mathrm{ml})$. Incubation was stopped by adding $39 \mu$ of ice cold $\mathrm{HClO}_{4}$ $(10 \mathrm{M})$. The cAMP content was evaluated by the radioimmunological method of Cailla et al. (1973) except that bound and free ligand were separated by precipitating the bound ligand with a mixture of $\gamma$-globulins $(2.5 \mathrm{mg} / \mathrm{ml})$ in citrate buffer (pH 7.2) and polyethyleneglycol $6000(20 \%$ $(\mathrm{w} / \mathrm{v}))$.

\section{Protein measurement}

The amount of protein in each assay was estimated on cell pellets after solubilization in $\mathrm{NaOH}(0 \cdot 1 \mathrm{M})$ using the method of Lowry et al. (1951). Bovine serum albumin fraction $\mathrm{V}$ was used as a standard.

\section{Plasma membrane preparation}

Washed cells were resuspended in ice cold Tris- $\mathrm{HCl}$ $(20 \mathrm{mM}) \mathrm{pH} 7.5$ containing sucrose $(250 \mathrm{mM})$, dithiothreitol $(0 \cdot 1 \mathrm{mM})$ and protease inhibitors (aprotinin $\left(10^{-5}\right.$ $\mathrm{g} / \mathrm{ml})$, phenylmethylsulphonylfluoride $\left(10^{-4} \mathrm{M}\right)$, leupeptin $\left.\left(10^{-5} \mathrm{~g} / \mathrm{ml}\right)\right)$. After homogenization and centrifugation $(30000 \mathrm{~g}, 20 \mathrm{~min})$, the membranes were assayed for phosphatase activity.

\section{Polyacrylamide gel electrophoresis and detection of phosphatase} activity

Electrophoresis was performed on a 7.5\% (v/v) homogeneous polyacrylamide gel in $25 \mathrm{mM}$ Tris, $192 \mathrm{mM}$ glycine, $0 \cdot 1 \%$ SDS (w/v) (pH 8.3) according to Laemmli (1970). Membrane samples were suspended in $62.5 \mathrm{mM}$ Tris- $\mathrm{HCl}$ pH 6.8 buffer containing $8 \%$ glycerol (v/v), bromophenol blue and 1\% SDS (w/v). Before loading the gel, the membrane samples were not boiled in order to reveal an enzymatic activity directly in the gel after the run. Prestained molecular weight markers were used as standards. After the run, the gel was washed twice with $100 \mathrm{mM}$ Tris $-\mathrm{HCl}(\mathrm{pH}$ 7). To reveal phosphatase activity, the gel was directly incubated for $30 \mathrm{~min}$ at $37^{\circ} \mathrm{C}$ in $100 \mathrm{mM}$ Tris-HCl (pH 7) containing both $1 \mathrm{mM}$ naphthol-AS biphosphate and $10 \mathrm{mM}$ Fast Red RC salt. Naphthol-AS biphosphate, a substrate of phosphatase, is in solution in Tris buffer and so accessible to the proteins in the gel. Used in conjunction with Fast Red RC salt, it produces an insoluble red end-product that can be observed visually directly in the gel.

Phosphatase activity was evidenced by a red coloured band after an incubation of $30 \mathrm{~min}$. When tested, inhibitors (vanadate and okadaic acid) were co-incubated with naphthol phosphate and Fast Red in Tris buffer. 


\section{Statistical evaluation}

Mean values of triplicate determinations were given with standard errors of the mean (s.E.M.). The statistical significance of differences was calculated using Student's $t$-test. $P$ values referring to corresponding controls are indicated in the figure legends.

\section{Results}

\section{cAMP-dependence of PTPase activity}

We have previously demonstrated that PTPase activity of thyroid cells was chronically dependent on the TSH concentration (from 0.01 to $1 \mathrm{mU} / \mathrm{ml}$ ). To study the modulation by cAMP of the PTPase activity, thyroid cells were incubated with agents known to activate the cAMP generating system like forskolin or with cAMP analogues such as 8-bromo-cAMP. Thyroid cells were incubated with various concentrations of 8-bromo-cAMP (Fig. 1A) or forskolin (Fig. 1B) and PTPase activity was measured after a 4-day culture period. Results demonstrate that PTPase activity is dependent on the concentration of either 8-bromo-cAMP or forskolin. PTPase activity of cells treated with either $10^{-3} \mathrm{M}$ 8-bromo-cAMP or $10^{-4} \mathrm{M}$ forskolin is similar to that of cells incubated with TSH $(0 \cdot 1 \mathrm{mU} / \mathrm{ml})$. The effect of forskolin is specific because no effect is observed with dideoxyforskolin, a structural analogue of forskolin that does not activate adenylyl cyclase (Fig. 1B).

Variations of adenylyl cyclase sensitivity, protein binding iodine and PTPase activity during the culture time

A low concentration of TSH $(0 \cdot 1 \mathrm{mU} / \mathrm{ml})$ is known to influence isolated thyroid cells to reorganize into folliclelike structures. Thyroid differentiated state is mainly associated with a high adenylyl cyclase sensitivity to acute TSH stimulation, thyroglobulin synthesis and secretion and ability of trapping iodine from the culture medium. In these experiments, thyroid cells were incubated with $0.1 \mathrm{mU} \mathrm{TSH} / \mathrm{ml}$ (TSH-treated cells) or without TSH (control cells) and three parameters were evaluated on each day of the culture: PTPase activity and adenylyl cyclase sensitivity in a first part (Fig. $2 A$ ), and PTPase activity and protein-binding iodine in a second part (Fig. $2 B)$. As previously described, TSH $(0.1 \mathrm{mU} / \mathrm{ml})$ induces an increase of adenylyl cyclase sensitivity and proteinbinding iodine during the culture time. Our results demonstrate that PTPase activity of TSH-treated cells is always higher versus control cells but spectacularly increases between the third and the fourth day of the culture. On the contrary, PTPase activity of control cells remains at a basal level. The difference between control and TSH-treated cells is significative as soon as the first day and is more pronounced at the third day of the culture.
Influence of PMA

PMA is known to induce large modifications in cultured thyroid cell morphology and metabolism. The effect of PMA on PTPase activity was studied using two protocols. In the first protocol, thyroid cells were incubated with either $0.1 \mathrm{mU} \mathrm{TSH} / \mathrm{ml}$ or $10^{-7} \mathrm{M}$ PMA, and PTPase activity was evaluated each day of the culture (Fig. $3 A$ ). As previously described, PTPase activity of TSH-treated cells progressively increases during the culture period from day 1 to day 4. Chronic treatment with PMA significantly inhibits PTPase activity as soon as the first day of the culture. PTPase activity of PMA-treated cells is similar to that of control cells incubated without TSH.

In the second protocol, thyroid cells were cultured for a first period of 2 days with $0.1 \mathrm{mU} \mathrm{TSH} / \mathrm{ml}$ followed by a second period of 2 days with either $0.1 \mathrm{mU} \mathrm{TSH} / \mathrm{ml}$ or $10^{-7}$ M PMA (Fig. 3B). As soon as $8 \mathrm{~h}$ incubation, PMA induces inhibition of PTPase activity. This inhibition persists during the second period from day 2 to day 4, so demonstrating that PMA counteracts action of TSH. The effect of GF 109203X, a specific inhibitor of protein kinase C, was also studied (Table 1). Co-incubated with cells in the presence of PMA, GF 109203X abolishes the action of PMA on PTPase activity and the inhibition is dose dependent.

\section{Analysis of PTPase}

TSH-dependent PTPase activity was previously demonstrated to be located at the external side of the membrane. So, membrane samples from TSH-treated cells were analysed by PAGE-SDS. Electrophoresis was followed by gel incubation with naphthol phosphate and Fast Red in order to visualize a phosphatase activity. Used in conjunction with Fast Red salt, hydrolysed naphthol phosphate produces an insoluble red end-product which can be observed directly in the gel. In these conditions, phosphatase activity of TSH-treated cells was evidenced at $111 \mathrm{kDa}$ (Fig. 4, lane a).

To address the specificity of the phosphatase, the activity was tested in the presence of either $10^{-5} \mathrm{M}$ vanadate, an inhibitor of protein-tyrosine phosphatase, or $10^{-8} \mathrm{M}$ okadaic acid, an inhibitor of phosphoserine phosphatase. Vanadate (Fig. 4, lane c) inhibits the phosphatase activity at $111 \mathrm{kDa}$ whereas okadaic acid (Fig. 4, lane d) has no effect, indicating that p111 is a phosphotyrosine phosphatase. Analysis of membranes prepared from PMA-treated cells shows that PTPase activity is significantly reduced by PMA incubation (Fig. 4, lane b).

\section{Discussion}

Thyroid cells in primary culture provide an interesting model to study both proliferation and/or differentiation 

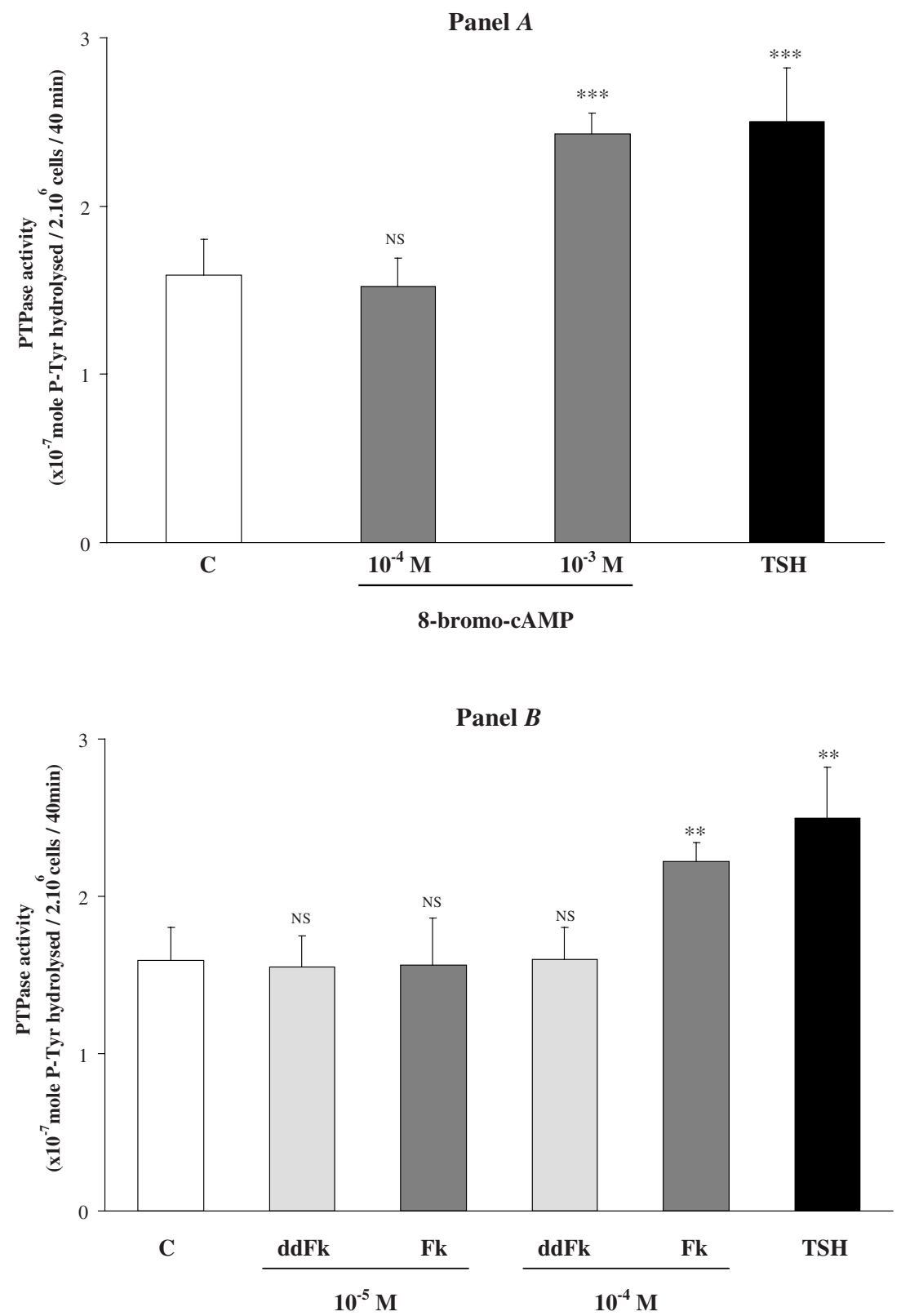

Figure 1 PTPase activity of thyroid cells. Cells were incubated with various concentrations of 8-bromo-cAMP $(A)$ or dideoxyforskolin (ddFk) or forskolin (Fk) (B). C: cells incubated without TSH and TSH: cells incubated with $0 \cdot 1 \mathrm{mU} \mathrm{TSH} / \mathrm{ml}$. After incubation for 4 days, cells were washed and PTPase activity was evaluated by phosphotyrosine hydrolysis as described in Materials and Methods and expressed as number of mole of phosphotyrosine (P-Tyr) hydrolysed $/ 2 \times 10^{6}$ cells per $40 \mathrm{~min}$. Results are the means \pm S.E.M. Of three experiments. NS, non significant, ${ }^{* *} P<0 \cdot 01,{ }^{* *} P<0 \cdot 001$ vs control cells (C).

expression. Proliferation and differentiation are considered antagonistic and the balance between these two processes is mainly controlled by TSH. TSH induces isolated thyroid cells to reorganize into functional follicles that mimic the physiological situation. Polarized cells constituting these follicles exhibit differentiated functions including iodine organification capacity, adenylyl cyclase sensitivity, expression of thyroglobulin and thyroperoxidase genes, synthesis of extracellular matrix proteins (Mauchamp et al. 1979, Garbi et al. 1988, Wegrowski et al. 1989, Dumont 

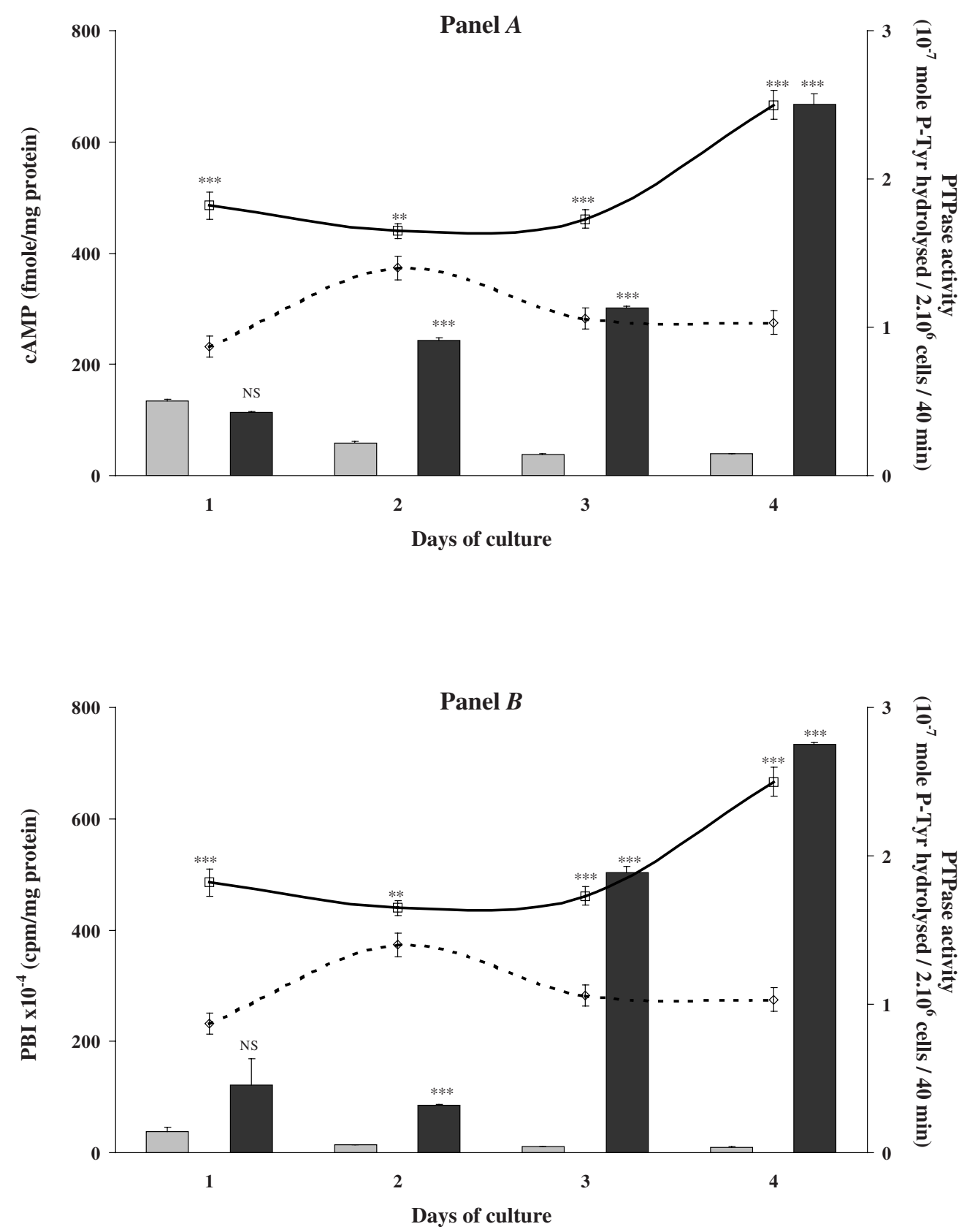

Figure 2 Variations of adenylyl cyclase activity, protein binding iodine and PTPase activity. Cells were incubated with $0.1 \mathrm{mU} / \mathrm{ml}$ TSH or without TSH, and parameters were evaluated each day of the culture. Curves represent PTPase activity (number of mole of phosphotyrosine (P-Tyr) hydrolysed $/ 2 \times 10^{6}$ cells per $40 \mathrm{~min}$ ) of control cells incubated without TSH (-- ) and TSH-treated cells (-). (A) Adenylyl cyclase sensitivity (fmol cAMP/mg protein) of control cells (shaded bars) and TSH-treated cells (solid bars). ( $B$ ) Protein binding iodine (PBI, c.p.m./mg protein) of control cells (shaded bars) and TSH-treated cells (solid bars). Results are the means \pm S.E.M. of one representative experiment. NS, non significant, ${ }^{* *} P<0 \cdot 01,{ }^{* * *} P<0 \cdot 001$.

et al. 1992). It has been demonstrated that tyrosine phosphorylation also influences junction assembly and so thyroid follicular morphogenesis (Yap et al. 1997). Most studies on thyroid cells have focused on intracellular phosphatases and kinases. In that way, earlier studies have suggested that TSH modulates tyrosine phosphorylation of 


\section{Panel $A$}

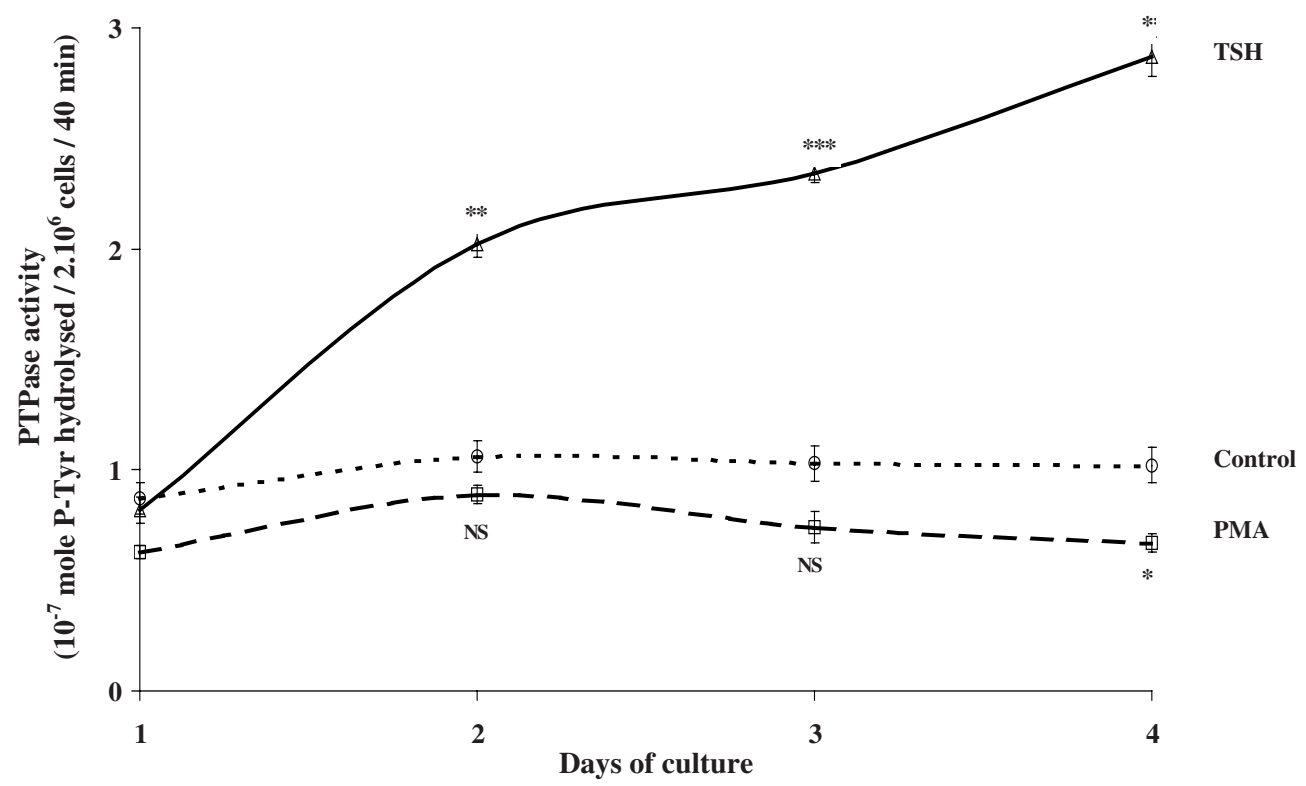

Panel $B$

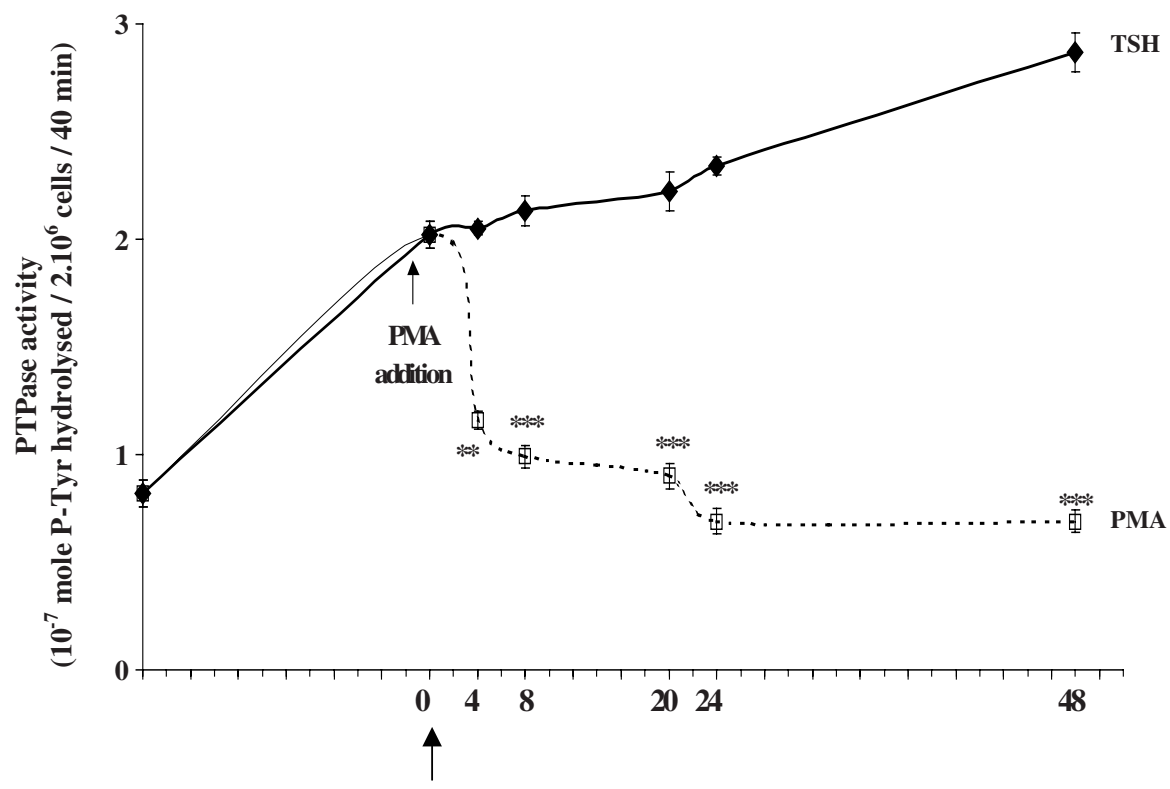

Hours after PMA addition

Figure $3(A)$ Cells were left untreated $(\bigcirc)$ or incubated with either $0 \cdot 1 \mathrm{mU} \mathrm{TSH} / \mathrm{ml}(\triangle)$ or $10^{-7} \mathrm{M} \mathrm{PMA}(\square)$ and PTPase activity was evaluated from day 1 to day 4 and expressed as number of moles of phosphotyrosine (P-Tyr) hydrolysed $/ 2 \times 10^{6}$ cells per $40 \mathrm{~min}$ ). Results are the means \pm S.E.M. of three experiments. $(B)$ Cells were incubated for 2 days with $0 \cdot 1 \mathrm{mU} \mathrm{TSH} / \mathrm{ml}$, washed and incubated with either $10^{-7} \mathrm{M} \mathrm{PMA}(\square)$ or $0 \cdot 1 \mathrm{mU} \mathrm{TSH} / \mathrm{ml}(\diamond)$. PTPase activity was evaluated from 0 to $48 \mathrm{~h}$ after PMA addition and expressed as number of moles of phosphotyrosine (P-Tyr) hydrolysed/2 $\times 10^{6}$ cells per $40 \mathrm{~min}$. NS, non significant, ${ }^{*} P<0 \cdot 05,{ }^{*} P<0 \cdot 01,{ }^{* *} P<0 \cdot 001$. 
Table 1 Effect of GF 109203X (GF) on PMA-induced inhibition of PTPase activity. After incubation for 2 days with $0 \cdot 1 \mathrm{mU} / \mathrm{ml} \mathrm{TSH}$, thyroid cells were washed and incubated with $0.1 \mathrm{mU} / \mathrm{ml}$ TSH or $10^{-7} \mathrm{M}$ PMA in the absence or presence of various concentrations of GF 109203X. After $20 \mathrm{~h}$ incubation, PTPase activity was evaluated as described in Materials and Methods and expressed as number of moles of P-Tyr hydrolysed $/ 2 \times 10^{6}$ cells per $40 \mathrm{~min}$. Results are the means \pm S.E.M. of three separate experiments. The effect of PMA is statistically significant compared with TSH treatment. The effects of GF are compared with that of PMA alone

\section{PTPase activity}

$\left(\times 10^{-7}\right.$ mol P-Tyr hydrolysed/ $2 \times 10^{6}$ cells per $40 \mathrm{~min}$ )

\section{Cell treatment}

TSH

PMA $10^{-7} \mathrm{M}$

PMA $10^{-7} \mathrm{M}+\mathrm{GF} 5 \times 10^{-6} \mathrm{M}$

PMA $10^{-7} \mathrm{M}+\mathrm{GF} 10^{-6} \mathrm{M}$

PMA $10^{-7} \mathrm{M}+\mathrm{GF} 10^{-7} \mathrm{M}$

PMA $10^{-7} \mathrm{M}+\mathrm{GF} 10^{-8} \mathrm{M}$

\begin{abstract}
$2 \cdot 62 \pm 0 \cdot 29$
$0 \cdot 84 \pm 0 \cdot 03^{* * *}$

$2 \cdot 60 \pm 0 \cdot 21^{* * *}$

$1 \cdot 94 \pm 0 \cdot 30^{* *}$

$1 \cdot 10 \pm 0 \cdot 01^{* *}$

$0 \cdot 85 \pm 0 \cdot 08^{\mathrm{NS}}$
\end{abstract}

NS, non significant, ${ }^{* *} P<0 \cdot 01,{ }^{* * *} P<0 \cdot 001$.

intracellular proteins in rat thyroid cells (Takahashi et al. 1991, Takano et al. 1995).

In a previous report, we identified an ectophosphotyrosine phosphatase (PTPase) activity in primary cultured pig thyroid cells. Specific substrates and various inhibitors allowed us to characterize this activity as a PTPase. This activity is enhanced by chronic treatment with $0.1 \mathrm{mU}$ $\mathrm{TSH} / \mathrm{ml}$ (Petitfrère et al. 1996). TSH biological effects on thyrocyte metabolism are largely mediated via cAMP (Dumont et al. 1989, Villone et al. 1993) and are mimicked by cAMP analogues and agents known to activate the cAMP generating system (Tramontano et al. 1988). Here, we demonstrate the cAMP dependence of PTPase activity

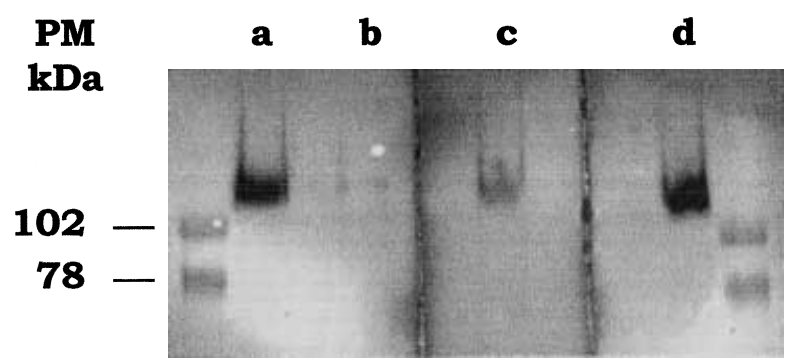

Figure 4 Electrophoresis of membrane preparations. After 4 days of incubation, cells were washed and membranes were prepared as described in Materials and Methods. After electrophoresis, polyacrylamide gel was incubated with naphthol phosphate and Fast Red as described in Materials and Methods to visualize PTPase activity. Prestained molecular weight markers were used as standards. Membranes were from $0 \cdot 1 \mathrm{mU} / \mathrm{ml} \mathrm{TSH}$-treated cells (lanes a, c, d) and $10^{-7} \mathrm{M}$ PMA-treated cells (lane b). Inhibitors were co-incubated with naphthol phosphate and Fast Red: $1 \times 10^{-5} \mathrm{M}$ vanadate (lane c) and $1 \times 10^{-8} \mathrm{M}$ okadaic acid (lane d). by using 8-bromo-cAMP, a structural analogue of cAMP and forskolin, a diterpene known to activate adenylyl cyclase. We also demonstrate that PTPase activity of TSH-treated cells increases from the first to the fourth day of culture while activity of control cells remains at the same basal level. An increase of differentiated functions, i.e. iodine organification or adenylyl cyclase sensitivity, is also observed in the same culture conditions as expected. These results suggest that TSH-induced PTPase activity could take place during folliculogenesis and consequently be considered as a differentiation marker. Indeed, follicular organization requires coordinated cellular aggregation and adhesion, intracellular trafficking and assembly of cell-cell junctions (Brabant et al. 1995, Gumbiner 1996). TSH preferentially increases thyroid cell-cell interactions, so inhibiting cell spreading and preserving follicular architecture (Yap et al. 1992, Yap \& Manley 1993). These observations could suggest that TSH-induced PTPase activity could be implied in cell-cell recognition or cell-cell adhesion that occur during follicle organization.

To confirm the idea that PTPase activity is correlated with a differentiated state of thyroid cells, we used PMA, a potent tumour promoter (Boutwell 1974). Indeed, PMA deeply affects thyroid cell metabolism, particularly iodination rate of thyroglobulin and sensitivity of adenylyl cyclase (Haye et al. 1985b). A characteristic aspect of thyroid cells incubated with PMA is also observed: cells adhere to substratum, spread out and form a monolayer after $20 \mathrm{~h}$ incubation with $10^{-7}$ M PMA (Haye et al. 1985c). So, PMA stimulates proliferation and inhibits differentiation of porcine thyroid cells in primary culture (Bachrach et al. 1985, Takasu et al. 1987). Our results show that chronic treatment with $10^{-7}$ M PMA inhibits significantly PTPase activity. We also demonstrate that PMA counteracts TSH effects. Indeed, after 2 days of incubation with TSH, PMA inhibits PTPase activity as soon as $8 \mathrm{~h}$ of treatment. This inhibition is abolished by GF 109203X, a specific inhibitor of protein kinase $\mathrm{C}$, suggesting that PTPase activity could be controlled by protein kinase C. In primary cultured thyroid cells, PMA provokes a rapid protein kinase C translocation to the membrane. This phenomenon and the accompanying activation are followed by a progressive inhibition leading to complete inactivation (Omri et al. 1988). PMA-induced PTPase inhibition could be associated either to the control of PTPase phosphorylation by protein kinase $\mathrm{C}$ or to a down-regulation of PTPase expression.

In our previous study reporting that PTPase activity was located at the outer surface of the thyroid cells, we attempted to demonstrate a PTPase activity from cell membranes. An original protocol using naphthol phosphate, a phosphatase substrate, and specific inhibitors, allowed us to visualize a PTPase activity at $111 \mathrm{kDa}$ directly from the polyacrylamide gel obtained after electrophoresis. With respect to molecular mass, PTPases can be divided into several categories ranging from high 
molecular mass (>100000 Da) to low molecular mass (15 $000 \mathrm{Da})$. The relationship between the different sized forms of PTPase in various tissues is unclear (Zhang 1997). We also confirm with this technique the drastic PMAinduced inhibition of the PTPase activity. The presence of PTPase in membranes of thyroid cells reinforces the hypothesis of a role for PTPase in cell-cell recognition during TSH-induced folliculogenesis. Indeed, the integrity of thyroid epithelial cell junctions involves a balance between a protein kinase and a transmembrane protein tyrosine phosphatase called РТР $\mu$ (Nilsson et al. 1996, 1998).

The nature of the physiological substrate of the PTPase remains to be established. To date, just a few ectocellular phosphatases have been described and little is known about their physiological substrate. In thyroid cells, connexins, constituents of the gap junctions, represent candidates for tyrosine phosphorylation (Bennett et al. 1991). Nevertheless, most connexins are preferentially phosphorylated by serine/threonine kinases and a phosphatase has never been implicated in the mechanism of dephosphorylation of connexins.

In conclusion, we have shown that PTPase activity is associated with a differentiated state of thyroid cells in primary culture and could be involved in cell-cell recognition occurring during TSH-induced folliculogenesis. PTPase could be a particularly useful tool for understanding the mechanisms leading to tumour progression. In this field, the purification from membranes will help us to characterize this PTPase. In a second step we will investigate the role of extracellular and sequencing matrix proteins as potential substrates for this enzyme.

\section{Acknowledgements}

This work was supported by grants from MENRT, CNRS and Ligue contre le Cancer (Comite de l'Aube). We thank Sobevir (Rethel, France) for providing thyroid glands. We thank Corinne Dauphin for typing the manuscript.

\section{References}

Bachrach LK, Eggo MC, Mak WW \& Burrow GN 1985 Phorbol esters stimulate growth and inhibit differentiation in cultured thyroid cells. Endocrinology 116 1603-1609.

Bellon G, Chaqour I, Antonicelli F, Wegrowski J, Claisse D, Haye B \& Borel JP 1994 Differential expression of thrombospondin, collagen and thyroglobulin by thyroid stimulating hormone and tumor-promoting phorbol ester in cultured porcine thyroid cells. Journal of Cellular Physiology 160 75-88.

Bennett MV, Barrio LC, Bargiello TA, Spray DC, Hertzberg E \& Saez JC 1991 Gap junctions: new tools, new answers, new questions. Neuron 6 305-320.

Boutwell RK 1974 The function and mechanism of promoters of carcinogenesis CRC. Critical Reviews in Toxicology 2 419-443.
Brabant G, Hoang-Vu C, Behrendo J, Cetin Y, Potter E, Dumont JE \& Maenhaut C 1995 Regulation of the cell-cell adhesion protein E-cadherin, in dog and human thyrocytes in vitro. Endocrinology 136 3113-3119.

Cailla HJ, Racine-Weisbuch MS \& Delaage MM 1973 Adenosine $3^{\prime}, 5^{\prime}$-cyclic monophosphate assay at $10^{-15}$ mole level. Analytical Biochemistry 56 394-407.

Charbonneau H \& Tonks NK 19921002 protein phosphatases? Annual Review of Cellular Biology 8 463-493.

Dumont JE, Jauniaux JC \& Roger PP 1989 The cyclic AMPmediated stimulation of cell proliferation. Trends in Biochemical Sciences 14 67-71.

Dumont JE, Lamy F, Roger PP \& Maenhaut C 1992 Physiological and pathological regulation of thyroid cell proliferation and differentiation by thyrotropin and other factors. Physiological Reviews 72 667-696.

Fayet G, Pacheco M \& Tixier R 1970 Reassociation in vitro of cells isolated from porcine thyroid and the biosynthesis of thyroglobulin. Conditions for the induction of cellular reassociations by thyreostimulin. Bulletins de la Société de Chimie et Biologie $\mathbf{5 2}$ 299-306.

Garbi C, Zurzolo C, Bifulco M \& Nitsch L 1988 Synthesis of extracellular matrix glycoproteins by a differentiated thyroid epithelial cell line. Journal of Cellular Physiology 135 39-46.

Gumbiner B 1996 Cell adhesion: the molecular basis of tissue architecture and morphogenesis. Cell 84 345-357.

Haye B, Aublin JL, Champion S, Lambert B \& Jacquemin C 1985a Chronic and acute effects of forskolin on isolated thyroid cell metabolism. Molecular and Cellular Endocrinology 43 41-50.

Haye B, Aublin JL, Champion S, Lambert B \& Jacquemin C 1985 b Effects of the chronic and acute treatments of pig thyroid cells with forskolin on the cyclic AMP accumulation and the phospholipid turnover. In Regulatory Peptides in Digestive, Nervous and Endocrine Systems, Inserm Symposium no. 25, pp 141-144. Eds MJM Lewin \& S Bonfils. Amsterdam: Elsevier.

Haye B, Aublin JL, Champion S, Lambert B \& Jacquemin C 1985c Tetradecanoyl phorbol-13-acetate counteracts the responsiveness of cultured thyroid cells to thyrotropin. Biochemical Pharmacology 34 3795-3802.

Laemmli UK 1970 Cleavage of structural proteins during the assembly of the head of bacteriophage T4. Nature 227 680-685.

Lowry OH, Rosebrough NF, Farr AL \& Randall RF 1951 Protein measurements with the Folin phenol reagent. Journal of Biological Chemistry 193 265-275.

Mauchamp JB, Margotat A, Chambard M, Charrier B, Remy L \& Michel-Bechet M 1979 Polarity of three dimensional structures derived from isolated hog thyroid cell in primary culture. Cell and Tissue Research 204 417-430.

Nilsson M, Fagman H \& Ericson LE $1996 \mathrm{Ca}^{2+}$-dependent and $\mathrm{Ca}^{2+}$-independent regulation of the thyroid epithelial junction complex by protein kinases. Experimental Cell Research 225 1-11.

Nilsson M, Husmark J, Bjorkman U \& Ericson LE 1998 Cytokines and thyroid epithelial integrity: interleukin-1 alpha induces dissociation of the junctional complex and paracellular leakage in filter-cultured human thyrocytes. Journal of Clinical Endocrinology and Metabolism 83 945-952.

Omri B, Breton MF, Haye B, Jacquemin C \& Pavlovic-Hournac M 1988 Phorbol ester prevents the thyroid-stimulating-hormoneinduced but not the forskolin-induced decrease of cAMP-dependent protein kinase activity in thyroid cell cultures. European Journal of Biochemistry 175 125-133.

Petitfrère E, Sartelet H, Aguie-Aguie G, Martiny L \& Haye B 1996 Evidence for a TSH-controlled ectophosphotyrosine phosphatase in pig thyroid cultured cells. Biochemical and Biophysical Research Communications 220 746-753.

Streuli M 1996 Protein tyrosine phosphatases in signaling. Current Opinions in Cell Biology 8 182-188. 
Takahashi SI, Conti M, Prokop C, Van Wyk JJ \& Shelton Earp H 1991 Thyrotropin and insulin-like growth factor I regulation of tyrosine phosphorylation in FRTL-5 cells. Journal of Biological Chemistry 266 7834-7841.

Takano T, Sumizaki H, Liu G \& Amino N 1995 Thyroid stimulating hormone and $\mathrm{N}^{6}-2^{\prime}$-O-dibutyryladenosine $3^{\prime}-5^{\prime}$-cyclic monophosphate decrease $110000-130000 \mathrm{Mr}$ tyrosinephosphorylated substrate in rat thyroid cells. Cellular Signalling 7 519-525.

Takasu N, Shimizu Y \& Yamada T 1987 Tumour promoter 12-Otetradecanoylphorbol 13-acetate and epidermal growth factor stimulate proliferation and inhibit differentiation of porcine thyroid cells in primary culture. Journal of Endocrinology 113 485-487.

Tramontano D, Moses AC, Veneziani BM \& Ingbar SH 1988 Adenosine $3^{\prime}, 5^{\prime}$-monophosphate mediates both the mitogenic effect of thyrotropin and its ability to amplify the response to insulin-like growth factor I in FRTL-5 cells. Endocrinology 122 127-132.

Villone G, Veneziani BM, Picone R, De Amicis F, Perrotti N \& Tramontano D 1993 In the thyroid cells proliferation, differentiated and metabolic functions are under the control of different steps on the cyclic AMP cascade. Molecular and Cellular Endocrinology 95 85-93.
Wegrowski J, Bellon G, Haye B \& Borel JP 1989 Effects of thyroidstimulating hormone and phorbol ester on glycosaminoglycan synthesis in porcine thyroid epithelial cells in primary culture. Cell Biology International Reports 13 881-890.

Yap AS \& Manley SW 1993 Contact inhibition of cell spreading: a mechanism for the maintenance of thyroid cell aggregation in vitro. Experimental Cell Research 208 121-127.

Yap AS, Abel KC, Bourke JR \& Manley SW 1992 Differential regulation of thyroid cell-cell and cell-substrate adhesion by thyrotropin. Experimental Cell Research 202 366-369.

Yap AS, Stevenson BR, Cooper V \& Manley SW 1997 Protein tyrosine phosphorylation influences adhesive junction assembly and follicular organization of cultured thyroid epithelial cells. Endocrinology 138 2315-2324.

Zhang ZY 1997 Structure, mechanism and specificity of protein tyrosine phosphatases. Current Topics in Cellular Regulation $\mathbf{3 5}$ $21-68$.

Received in final form 23 February 2001 Accepted 26 February 2001 